\title{
Bakteri Pendegradasi Solar Dari Sedimen Perairan Dalam Skala Laboratorium (In Vitro)
}

\author{
Bagus Enggal Prakoso*, Widianingsih, Sunaryo \\ Jurusan IImu Kelautan, Fakultas Perikanan dan IImu Kelautan, Universitas Diponegoro \\ JI. Prof. H. Soedarto S.H, Tembalang, Semarang, Jawa Tengah 50275 Indonesia \\ ${ }^{*}$ Corresponding author, e-mail : bagusenggalprakoso1997@gmail.com
}

\begin{abstract}
ABSTRAK: Pelabuhan Tanjung Mas adalah sebuah pelabuhan yang mengalami berbagai aktivitas seperti bongkar muat, aktivitas pelayaran, kapal bersandar dan lain-lain. Aktivitas antropogenik yang ada di area pelabuhan umumnya menyebabkan banyaknya jumlah minyak solar yang tumpah ke laut dan kemudian terakumulasi ke dalam sedimen dalam jangka waktu yang panjang. Jika hal ini terus terjadi maka akan mengganggu kehidupan biota demersal dan ekosistem di Pelabuhan Tanjung Mas. Oleh karena itu, perlu dilakukan upaya biodegradasi minyak solar menggunakan bakteri yang ramah lingkungan dan tepat. Tujuan penelitian ini dilakukan yaitu mendapatkan isolat bakteri sedimen yang mampu mendegradasi minyak solar dan mengetahui tingkat kemampuan isolat bakteri untuk mendegradasi minyak solar. Penelitian ini dilaksanakan pada bulan Juli sampai dengan Oktober 2019 dengan metode purpossive sampling, metode pour plate, metode gravimetri dan Standard Plate Count. Bakteri isolat yang didapat dari hasil isolasi sedimen kemudian diseleksi kembali menggunakan media SMSSe dan prosentase minyak solar $2 \%$. Pada seleksi awal dengan prosentase minyak solar $2 \%$ didapatkan 2 isolat bakteri yang mampu tumbah baik pada media SMSSe dan $2 \%$ prosentase minyak solar, yaitu bakteri dengan kode isolat ISL 2 dan ISL 3 . Kedua isolat bakteri hasil seleksi awal kemudian diidentifikasi dengan uji molekuler. Hasil dari uji molekuler menyatakan bahwa kedua isolat bakteri dengan kode ISL 2 dan ISL 3 berasal dari spesies yang sama, yaitu Vibrio alginolyticus. Isolat bakteri Vibrio alginlyticus yang didapat kemudian diuji daya degradasinya dengan menggunakan 2 prosentase minyak solar yang berbeda, yaitu prosentase $5 \%$ dan $10 \%$ dengan 2 pengulangan. Pada hasil uji degradasi menyatakan bahwa bakteri Vibrio alginolyticus dapat mendegradasi minyak solar yang ditambahkan pada media SMSSe. Bakteri Vibrio alginolyticus hasil isolasi mampu mendegradasi minyak solar hingga $0,8085 \mathrm{~mL}(80,85 \%)$ pada prosentase awal 10\% minyak solar $(1 \mathrm{~mL})$ dengan periode 14 hari $(\mathrm{H} 14)$.
\end{abstract}

Kata kunci: Bakteri; Sedimen; Biodegradasi; Minyak Solar; Tanjung Mas

\section{Bacteria of Solar Degradation from Water Sediments in the Laboratory Scale (In Vitro)}

ABSTRACT: Tanjung Mas Port is a port that experiences a variety of activities such as loading and unloading, shipping activities, leaning ships, and others. Generally, anthropogenic activity in the port area causes large amounts of diesel oil that spills into the sea and then accumulates into the sediment over a long period. If this continues, it will disrupt the lives of demersal biota and the ecosystem in Tanjung Mas Harbor. Therefore, it is necessary to do biodegradation of diesel oil using environmentally friendly and appropriate bacteria. The purpose of this study was to obtain bacterial sediment isolates that can degrade diesel oil and determine the ability of bacterial isolates to degrade diesel oil. This research was conducted from July to October 2019 using the purposive sampling method, pour plate method, gravimetric method, and Standard Plate Count. Bacteria isolates obtained from the results of sediment isolation were then reselected using SMSSe media and a percentage of $2 \%$ diesel oil. In the initial selection with a percentage of $2 \%$ diesel oil, 2 bacterial isolates were able to grow well on SMSSe media and $2 \%$ percentage of diesel oil, namely bacteria with isolate code ISL 2 and ISL 3. The two bacterial isolates from the initial selection were identified by molecular testing. The results of the molecular test stated that the two bacterial isolates with the code ISL 2 and ISL 3 came from the same species, namely Vibrio alginolyticus. The Vibrio alginolyticus bacterial isolate obtained was then tested for its degradation power using 2 different percentages of diesel oil, namely $5 \%$ and $10 \%$ with 2 repetitions. The results of the degradation test stated that the Vibrio alginolyticus bacteria could degrade the diesel oil added to the SMSSe medium. 
The isolated Vibrio alginolyticus bacteria can degrade diesel oil up to $0.8085 \mathrm{~mL}(80.85 \%)$ at the initial percentage of $10 \%$ diesel oil ( $1 \mathrm{~mL}$ ) with a period of 14 days (H14).

Keywords: Bacteria; Sediment; Biodegradation; Diesel Oil; Tanjung Mas

\section{PENDAHULUAN}

Pelabuhan Tanjung Mas adalah sebuah pelabuhan di Kota Semarang, Jawa Tengah yang berfungsi sebagai pusat atau simpul transportasi dengan skala lokal sampai skala internasional. Pada lokasi ini sering ditemukan berbagai aktivitas pelabuhan seperti bongkar muat, aktivitas pelayaran, kapal bersandar, dan lain-lain. Pelabuhan Tanjung Mas sebagai salah satu pelabuhan strategis di Indonesia mengalami kenaikan arus kedatangan kapal tiap tahunnya (Firdaus et al., 2013).

Menurut data Badan Pusat Statistik Provinsi Jawa Tengah tahun 2017, jumlah kapal yang ada di Pelabuhan Nusantara mengalami kenaikan pada tahun 2009 sebesar 830 unit kapal menjadi 1.166 unit kapal pada tahun 2014. Jumlah kapal tanker yang ada juga mengalami kenaikan yang cukup pesat pada tahun 2011 yaitu dari 138 unit kapal di tahun 2009 menjadi 212 unit. Total kapal pada tahun 2009 yaitu 2.474 unit kapal dan terus mengalami peningkatan sampai dengan tahun 2014 yaitu sebesar 2.590 unit kapal. Peningkatan jumlah kapal berdampak pada semakin banyaknya jumlah minyak yang tumpah ke lautan. Tumpahan minyak yang ditemukan di kawasan pelabuhan ini biasanya berasal dari proses mobilisasi kapal dan kecelakaan kapal. Salah satu contoh kecelakaan kapal yang baru saja terjadi di Pelabuhan Tanjung Mas, Semarang yaitu kecelakaan kapal tongkang menabrak crane bongkar muat di Terminal Peti Kemas Semarang.

Minyak yang masuk ke perairan akan mengalami dekomposisi kemudian masuk ke sedimen. Menurut Pratama (2018), endapan minyak di sedimen dapat terjadi akibat adanya aktivitas dari kapal seperti mobilisasi, pembuangan air pendingin kapal dan kebocoran kapal yang kemudian minyak tersebut masuk ke perairan dan mengendap di sedimen. Endapan minyak di sedimen menyebabkan kerusakan ekosistem laut. Campuran minyak mentah dan dispersan atau perbandingan masingmasing dapat menyebabkan peningkatan toksisitas di beberapa spesies fitoplankton.

Upaya yang bisa digunakan untuk menanggulangi tumpahan minyak di laut yaitu bioremediasi. Bioremediasi adalah proses pendegradasian bahan organik berbahaya secara biologis menjadi senyawa lain yang tidak berbahaya. Salah satu contoh agen bioremediasi adalah bakteri. Menurut Nasikhin et al (2013), ada beberapa jenis bakteri yang memiliki kemampuan untuk mendegradasi senyawa hidrokarbon salah satunya yaitu bakteri yang berasal dari genus Vibrio. Pada beberapa penelitian sebelumnya diketahui bahwa terdapat beragam jenis genus bakteri yang memiliki kemampuan degradasi secara signifikan. Nurjanah (2018), mengatakan bahwa bakteri dari genus Bacillus, genus Klebsiella, genus Enterobacter dan genus Citrobacter juga memiliki tingkat daya degradasi terhadap minyak solar yang signifikan.

Tujuan dari penelitian yaitu untuk mendapatkan dan mengidentifikasi isolat bakteri yang mampu mendegradasi minyak solar pada sedimen laut kawasan Pelabuhan Tanjung Mas Semarang serta mengetahui daya degradasi isolat bakteri terhadap minyak solar.

\section{MATERI DAN METODE}

Materi penelitian yang akan digunakan adalah sampel sedimen dari perairan Pelabuhan Tanjung Mas Semarang. Pengambilan sampel sedimen dilaksanakan pada 1 Juli 2019. Lokasi pengambilan sampel berada di Pelabuhan Tanjung Mas. Pelabuhan Tanjung Mas terletak di utara Kota Semarang tepatnya di Jalan Coaster No. 10, Tanjung Mas, Semarang Utara, Jawa Tengah.

Metode sampling yang digunakan yaitu purposive sampling method di 3 lokasi yang berada di kawasan PT Pelindo 3 Pelabuhan Tanjung Mas, Semarang. Koordinat lokasi pengambilan sampel ditentukan berdasarkan 3 tempat yang memiliki aktivitas berbeda yaitu tempat mobilisasi nelayan, pelabuhan bongkar muat dan pelabuhan tempat kapal penumpang bersandar.

Parameter perairan yang diamati meliputi suhu, salinitas, kadar oksigen terlarut, kecerahan perairan dan kecepatan arus. Alat yang digunakan pada saat pengambilan sampel sedimen meliputi 
grab sampler jenis ekman bottom, termometer raksa, refraktometer, DO meter, kertas $\mathrm{pH}$, secchi disk dan bola duga. Pengukuran parameter perairan dilakukan dengan tujuan mendapatkan kualitas perairan.

Metode yang digunakan untuk isolasi bakteri yaitu dengan menggunakan metode pour plate. Media yang digunakan adalah Stone Mineral Salt Solution Extract Yeast padat dengan penambahan prosentase minyak solar (v/v) (Yunita et al., 2015). Komposisi bahan media Stone Mineral Salt Solution Extract Yeast yaitu $\mathrm{CaCO}_{3} 5 \mathrm{~g} ; \mathrm{NH}_{4} \mathrm{NO}_{3} 2,5 \mathrm{~g} ; \mathrm{Na}_{2} \mathrm{HPO}_{4} .7 \mathrm{H}_{2} \mathrm{O}$ 1g; $\mathrm{KH}_{2} \mathrm{PO}_{4} \quad 0,5 \mathrm{~g}$; $\mathrm{MgSO}_{4} .7 \mathrm{H}_{2} \mathrm{O} 0,5 \mathrm{~g} ; \mathrm{MnCl}_{2} .7 \mathrm{H}_{2} \mathrm{O}$ 0,2g; Ekstrak Yeast 0,01\% dilarutkan dalam $1000 \mathrm{~mL}$ air suling/ aquades. Kemudian, media tersebut ditambahkan minyak solar dengan prosentase tertentu (v/v) sebagai sumber karbon, mengatur $\mathrm{pH}$ menjadi 6,8-7 dengan menggunakan $\mathrm{NaOH} 1 \%$ atau $\mathrm{HCl} 1 \%$ (Mijaya et al., 2019).

Sampel sedimen basah pada tiap stasiun diambil seberat $1 \mathrm{~g}$ dan ditambahkan kedalam medium SMSSe cair dengan kandungan prosentase minyak solar sebesar $2 \%(\mathrm{v} / \mathrm{v})$. Sampel sedimen kemudian dishaker selama 3x24 jam (3 hari) dengan kecepatan $120 \mathrm{rpm}$. Sampel kemudian diisolasi dengan metode pengenceran hingga $10^{-5}$ dengan menggunakan $\mathrm{NaCl}$ fisiologis steril dan dibiakkan dalam lempeng agar SMSSe dengan minyak solar $2 \%(\mathrm{v} / \mathrm{v})$ pada suhu $35^{\circ} \mathrm{C}$ untuk dilakukan Total Plate Count (TPC). Pada tahap penyeleksian ini diharapkan menghasilkan bakteri yang memiliki daya degradasi terhadap minyak solar.

Pada identifikasi spesies bakteri dilakukan uji molekuler untuk mengetahui jenis spesies apa saja yang telah didapat dari hasil pemurnian dengan menggunakan gen 16S rRNA. Pada uji molekuler ada beberapa tahapan yang dilakukan yaitu, Ekstraksi DNA, Amplifikasi, Elektroforesis, DNA sequencing dan analisa filogenetik. Uji Molekuler digunakan untuk mengidentifikasi isolat bakteri dari hasil penelitian yang didapat dan sebelumnya telah melalui tahap seleksi pada medium SMSSe dengan tambahan prosentase minyak solar.

Tahap ekstraksi DNA, supernatant yang mengandung genome DNA diambil dengan cara mencampurkan 3-4 goresan kecil sampel bakteri dengan larutan $20 \mu \mathrm{L} \mathrm{ddH}_{2} \mathrm{O}$ dan $1 \mathrm{~mL} 0,5 \%$ Saponin PBS $1 \mathrm{X}$ lalu diamkan di dalam microtube pada suhu $4^{\circ} \mathrm{C}$ selama semalam. Sampel kemudian dihomogenkan dengan menggunakan Centrifuge pada kecepatan 12.000 RPM selama 10 menit dan buang supernatant. Kemudian sampel kembali dicampurkan dengan $100 \mu \mathrm{L} \mathrm{dd}_{2} \mathrm{O}$ dan 50 $\mathrm{L}$ 20\% Chelex 100 serta dihomogenkan. Sampel dipanaskan hingga mendidih selama 10 menit dan Centrifuge sampel pada 12.000 RPM tiap 5 menitnya. Terakhir centrifuge kembali pada kecepatan 12.000 RPM selama 10 menit, pindahkan dan simpan supernatant yang mengandung genome DNA ke dalam microtube baru.

Amplifikasi digunakan untuk mereplikasi rantai DNA yang telah didapat dari hasil ekstraksi. Amplifikasi DNA dilakukan secara in vitro dengan menggunakan Polymerase Chain Reaction (PCR), proses amplifikasi DNA melibatkan manipulasi suhu untuk memulai prosesnya. Berikut adalah proses amplifikasi DNA, Denaturasi (suhu $90^{\circ} \mathrm{C}$ ) selama 3 menit, $20-40$ siklus Annealing $\left(55^{\circ} \mathrm{C}\right)$ selama 1 menit, dan ekstensi primer $\left(72^{\circ} \mathrm{C}\right)$ selama 7 menit (Handoyo et al, 2000). Pada amplifikasi DNA bakteri, primer yang digunakan adalah primer 27F Forward Strand (5'-AGAGTTTGATCMT GGCTCAG-3') dan primer 1492R Reverese Strand (5'-TACGGYTACCTTGTTACGACTT-3') 16S rRNA (Fredriksson et al., 2013).

Elektroforesis DNA dilakukan untuk mengetahui panjang rantai DNA. Elektroforesis dilakukan dengan memasukkan sampel supernatant genome DNA ke dalam gel elektroforesis dan diberi daya listrik yang telah disesuaikan $50-60 \mu \mathrm{A}, 50-60 \mu \mathrm{A}$ atau $45-55 \mu \mathrm{A}$ selama kurang lebih 3 jam. Sampel gel kemudian divisualisasi dengan alat Biobase Gel System untuk mengamati gel band yang terbentuk. Proses DNA sequencing dan analisa filogenetik dilakukan menggunakan software MEGA6. Sekuen DNA yang telah didapat selanjutnya diolah kembali menggunakan software Mega6 untuk melakukan alignment rantai DNA. Proses alignment rantai DNA dilakukan dengan memotong noise pada kedua forward dan reverse rantai sekuen kemudian pilih metode alignment sequences with muscle dan keduanya digabungkan hingga menjadi satu rantai sekuen yang sama. Pada pembuatan pohon filogenetik, pilih opsi model Tamamura-Nei model dan menggunakan metode neighbor joining tree. Tamamura-Nei method merupakan model yang umum dipilih untuk membuat pohon filogenetik. Menurut Dharmayanti (2011), metode neighbor joining tree dapat memberikan estimasi panjang cabang sangat baik antar masing-masing sekuen DNA. 
Pada pembuatan pohon filogenetik ini diuji secara statistik menggunakan metode bootstrap replications sebanyak 1000 kali pengulangan. Penggunaan metode bootstrap ini bertujuan untuk meningkatkan nilai kepercayaan pada topologi pohon filogenetik, dengan kata lain semakin tinggi nilai bootstrap replication maka semakin tinggi nilai kepercayaannya (Ubaidillah, 2009).

Setelah mendapatkan isolat bakteri yang mampu mendegradasi minyak solar pada prosentase $2 \%$, isolat bakteri Vibrio alginolyticus diuji daya degradasinya dengan menggunakan dua prosentase minyak solar yang berbeda, yaitu prosentase $5 \%$ dan $10 \%$ yang ditambahkan pada medium SMSSe cair (v/v). Isolat bakteri yang telah dimurnikan sejumlah $10^{-5} \mathrm{sel} / \mathrm{mL}$, diambil $1 \mathrm{~mL}$ lalu ditambahkan ke dalam medium SMSSe cair yang mengandung minyak solar 5\% dan 10\% secara terpisah. Bakteri hasil kultur diinkubasi pada suhu ruang dan digoyang di atas shaker dengan kecepatan 120 rpm selama $7 \times 24$ jam (7 hari) dan 14x24 jam (14 hari). Estimasi kepadatan bakteri dilakukan pada hari ke-7 dan 14 dengan metode Standart Plate count (SPC) untuk menghitung jumlah koloni bakteri.

Analisa degradasi minyak dilakukan dengan tujuan untuk mengetahui sisa minyak dari hasil degdradasi. Pada tahapan ini, minyak sisa hasil degdradasi diamati jumlah prosentasenya. Medium hasil sisa degradasi dicampurkan pelarut $n$-Hexane sebanyak $15 \mathrm{~mL}$ ke dalam $10 \mathrm{~mL}$ media, pencampuran ini bertujuan agar hasil sisa minyak degradasi larut bersama dengan pelarut dan terpisah dengan medium cairnya. Setelah dicampur pelarut, minyak hasil sisa dipisahkan dengan mediumnya menggunakan corong pemisah. Minyak yang telah dicampur pelarut tersebut kemudian disaring dengan kertas saring yang telah dioles $\pm 0,5 \mathrm{~g} \mathrm{Na}_{2} \mathrm{SO}_{4}$ pada permukaannya, kemudian larutan sampel dipanaskan pada titik didih pelarut $n$-Hexane yakni $60^{\circ} \mathrm{C}$ untuk memisahkan pelarut dan minyak dengan proses penguapan menggunakan alat destilator. Labu alas bulat setelah proses dan sebelum proses destilasi dihitung beratnya.

\section{HASIL DAN PEMBAHASAN}

Lokasi pengambilan sampel sedimen berada di 3 stasiun berbeda di kawasan Pelabuhan Tanjung Mas, Semarang. Stasiun 1 berada pada koordinat 0656'59,92" S 110²5'08,19" E. Lokasi stasiun 1 berada di alur pelayaran dari dan menuju Kolam Pelabuhan. Kolam Pelabuhan sering digunakan untuk tempat bersandar kapal. Stasiun 2 berada pada koordinat 0656'50,88" S $110^{\circ} 25^{\prime} 15,85^{\prime \prime}$ E. Stasiun ini terletak di antara Pelabuhan Dalam 1 dan Terminal Nusantara. Aktivitas manusia yang umum ada pada stasiun ini yaitu kegiatan naik turun penumpang dan bongkar-muat barang terutama kayu. Stasiun 3 berada pada koordinat 0656'27,86" S 110²5'16,30" E dan berlokasi di dekat Semarang Container Terminal. Pada lokasi ini, kegiatan bongkar muat peti kMas merupakan kegiatan yang dominan ada pada Container Terminal (Gambar 1).

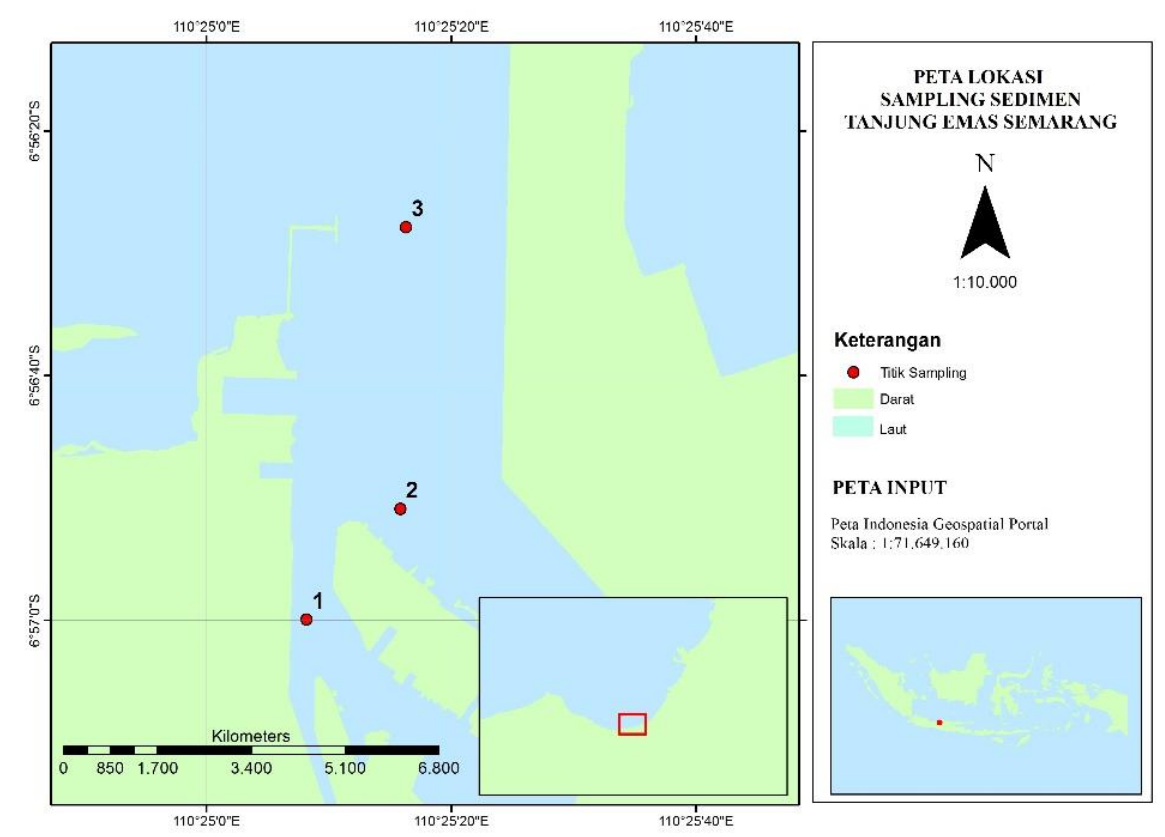

Gambar 1. Peta Lokasi Pengambilan Sampel Tanjung Mas Semarang 
Dari hasil pengukuran parameter perairan diperoleh data salinitas, $\mathrm{pH}$, kecerahan, arus, Dissolved oxygen, suhu dan kedalaman. Salinitas yang diukur bernilai sama pada tiap stasiun yaitu 30 ppt. Nilai $\mathrm{pH}$ pada tiap stasiun juga bernilai sama yaitu 7 . Kecerahan perairan pada lokasi pengambilan sampel berkisar antara $91.25 \mathrm{~cm}$ hingga $161,5 \mathrm{~cm}$. Kecepatan arus memiliki sedikit perbedaan yakni berkisar $0,1 \mathrm{~m} / \mathrm{s}$ hingga $0,12 \mathrm{~m} / \mathrm{s}$. Setiap stasiun memiliki kadar oksigen terlarut (Dissolved oxygen) yang bervariasi yakni berkisar antara $5,83 \mathrm{mg} / \mathrm{L}$ hingga $6,83 \mathrm{mg} / \mathrm{L}$. Suhu perairan saat pengambilan sampel tidak berbeda jauh pada setiap stasiunnya yakni berkisar antara $27,8^{\circ} \mathrm{C}$ hingga $29,9^{\circ} \mathrm{C}$. Kedalaman pada setiap stasiun meimiliki perbedaan yakni berkisar antara 5 meter hingga 11 meter (Tabel 1). Data parameter perairan yang didapat memiliki kemiripan dengan hasil penelitian Wulandari et al. (2014), suhu, salinitas, pH dan arus secara berturut-turut berkisar 28$32^{\circ} \mathrm{C}, 31-32,5$ ppt, 6,7-7,9, 0,0222 - 0.1985 m/detik. Kadar oksigen terlarut (DO) memiliki nilai yang lebih tinggi yaitu berkisar 7,1-8,3 ppm.

Isolat bakteri dengan kode ISL 2 dan ISL 3 diketahui mampu tumbuh dan mendegradasi minyak solar pada medium SMSSe cair yang telah ditambahkan $2 \%$ prosentase minyak solar ( $\mathrm{v} / \mathrm{v}$ ). Isolat bakteri hasil seleksi kemudian diidentifikasi melalui pengamatan makroskopik dan mikroskopik untuk mengetahui jenis gram dan karakteristik bentuk koloninya. Setelah dilakukan pengamatan, diketahui kedua bakteri tersebut merupakan jenis bakteri gram negatif karena hasil pewarnaan menunjukkan warna merah (Tabel 2).

Tabel 1. Parameter fisika kimia di lokasi penelitian

\begin{tabular}{llll}
\hline \multirow{2}{*}{ Parameter } & \multicolumn{4}{c}{ Stasiun } \\
\cline { 2 - 4 } & \multicolumn{4}{c}{$\mathbf{3}$} \\
\hline Salinitas (ppt) & 30 & 30 & 30 \\
$\mathrm{pH}$ & 7 & 7 & 7 \\
Kecerahan $(\mathrm{cm})$ & 161,5 & 91,25 & 112,95 \\
Arus $(\mathrm{m} / \mathrm{s})$ & 0,1 & 0,12 & 0,1 \\
DO $(\mathrm{ppm})$ & 5,83 & 6,83 & 6,64 \\
Suhu $\left({ }^{\circ} \mathrm{C}\right)$ & 29.4 & 27.8 & 29.9 \\
Kedalaman $(\mathrm{m})$ & 5 & 7 & 11 \\
\hline
\end{tabular}

Tabel 2. Morfologi Bakteri

\begin{tabular}{llll}
\hline \multirow{2}{*}{ Pengamatan } & \multicolumn{1}{c}{ Karakteristik } & \multicolumn{2}{c}{ Kode Isolat } \\
\cline { 3 - 4 } Makroskopik & Ukuran Koloni & Kecil & ISL 2 \\
& Bentuk Koloni & Bulat & Kecil \\
& Tepi Koloni & Berombak & Bulat \\
& Warna Koloni & Putih & Rata/utuh \\
& Elevasi Koloni & Timbul/Melengkung & Putih \\
Mikroskopik & Pewarnaan Gram & Negatif & Datar \\
& Bentuk Sel & Batang & Begatif \\
& & & Batang \\
\hline
\end{tabular}

Uji molekuler dilakukan untuk mengetahui jenis spesies dari isolat bakteri yang didapatkan dari proses seleksi awal. Pada tahap visualisasi gel elektroforesis dalam uji molekuler diketahui bahwa jumlah pasangan basa DNA pada isolat ISL 2 dan ISL 3 berkisar 1500 bp. Keterangan nomor 1 merupakan hasil visualisasi isolat dengan kode ISL 2, nomor 2 merupakan isolat dengan kode ISL 3 (Gambar 2).

Pada proses sekuensing DNA, data sekuen hasil molekuler yang berupa primer reverse dan forward dikoreksi (alignment) sehingga noise pada rantai DNA berkurang. Pemotongan noise pada rantai DNA sekuen dilakukan pada software MEGA6 dengan cara memotong dan mengoreksi rantai DNA sekuen tersebut. DNA sekuen yang telah dikoreksi kemudian dianalisa pohon filogenetiknya dengan pengulangan/Bootstrap Replication sebanyak 1000 kali. Pembuatan pohon filogenetik spesies menggunakan 16 data spesies terdekat dan 1 spesies dari genus Salmonella sp. sebagai data pembanding. 


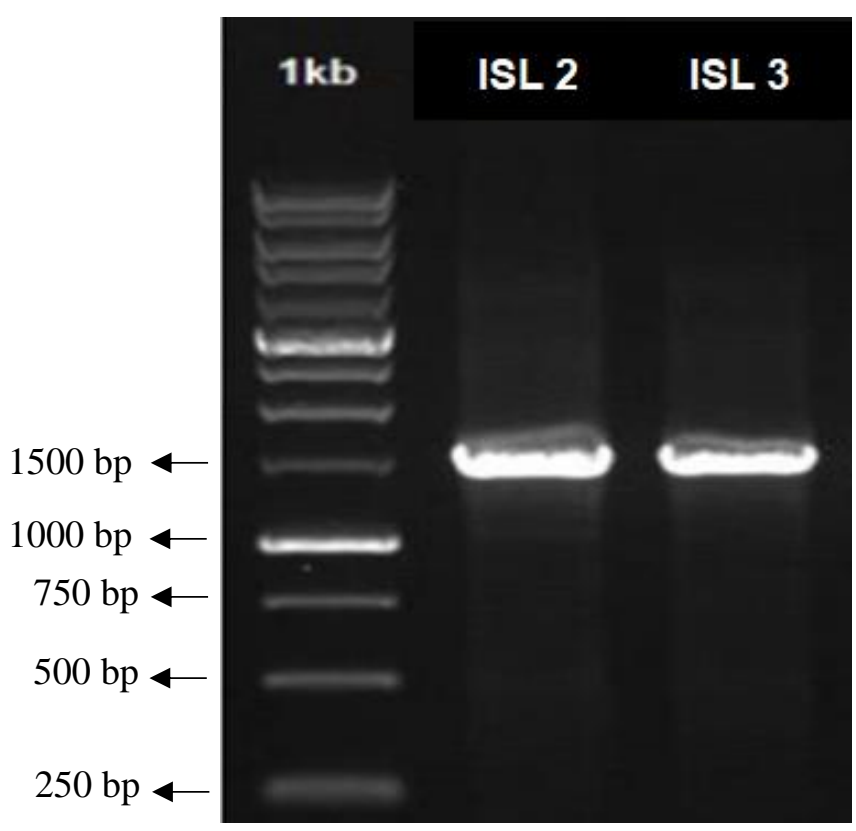

Gambar 2. Hasil Visualisasi Elektroforesis

Tabel 3. Identifikasi molekuler

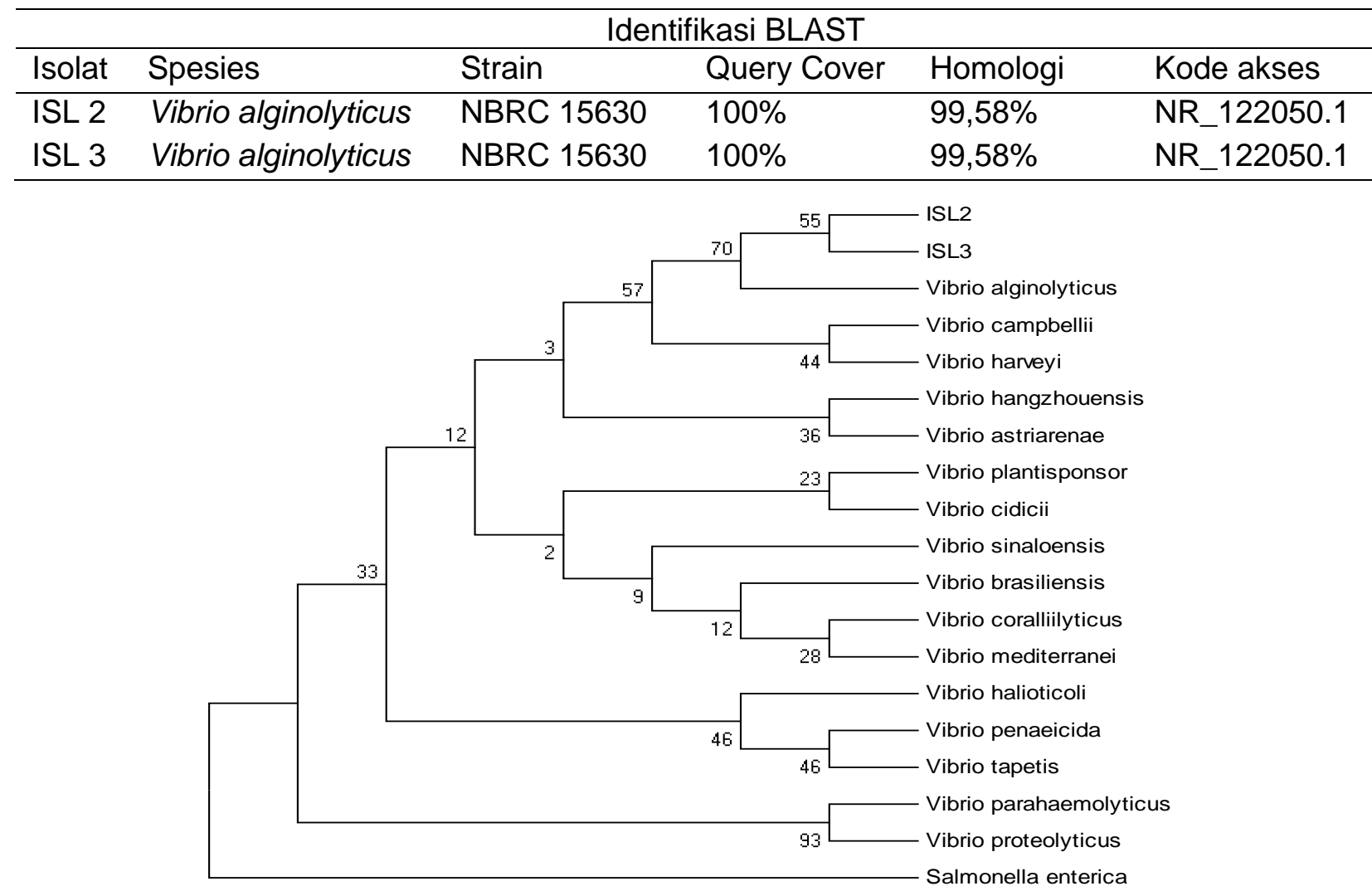

Gambar 3. Hasil Analisis Filogenetik Mega6

Hasil analisa sekuen pada uji molekuler dari sekuen DNA isolat bakteri ISL 2 dan ISL 3 menunjukkan bahwa jenis spesies kedua bakteri memiliki kemiripan hingga 99,58\% dengan spesies bakteri Vibrio alginolyticus. Bakteri Vibrio alginolyticus diketahui merupakan bakteri yang dapat mendegradasi minyak solar, hal ini juga diperkuat dari hasil penelitian yang dilakukan Imron dan 
Titah (2018), yang menyatakan bahwa bakteri spesies Vibrio alginolyticus mempunyai kemampuan untuk mendegradasi minyak solar pada prosentase tertentu. Analisis filogenetik digunakan untuk mengetahui kekerabatan masing-masing isolat dengan bakteri lain yang ada di BLAST berdasarkan urutan DNA. Hasil identifikasi kedua isolat dijelaskan dalam tabel 6 dan pohon filogenetik divisualisasikan pada Gambar 3.

Isolat bakteri Vibrio alginolyticus dari hasil isolasi dan seleksi kemudian diuji kemampuan degradasinya terhadap minyak solar. Media tumbuh bakteri yang digunakan pada uji degradasi minyak, yaitu SMSSe dengan dua prosentase berbeda, 5\% dan 10\%. Periode isolasi pada uji minyak, yaitu 7 hari dan 14 hari. Jumlah kepadatan awal bakteri Vibrio alginolyticus, yaitu sebanyak 0,00054 $10^{5} \mathrm{CFU} / \mathrm{mL}$. Vibrio alginolyticus ditumbuhkan ke dalam media SMSSe dengan minyak solar prosentase $5 \%$ dan $10 \%$.

Hasil pertumbuhan kedua isolat dihitung pada hari ke 7 dan ke 14. Kepadatan bakteri Vibrio alginolyticus ulangan pertama pada prosentase $5 \%$ mengalami penurunan dari $1,4 \times 10^{5} \mathrm{CFU} / \mathrm{mL}$ pada hari ke 7 menjadi $1,1 \times 10^{5} \mathrm{CFU} / \mathrm{mL}$. Jumlah kepadatan bakteri Vibrio alginolyticus ulangan pertama dengan prosentase minyak solar $10 \%$, yaitu $6,1 \times 10^{5} \mathrm{CFU} / \mathrm{mL}$ pada hari ke 7 dan $0,5 \times 10^{5}$ $\mathrm{CFU} / \mathrm{mL}$ pada hari ke 14 (Tabel 4).

Bakteri Vibrio alginolyticus ulangan ke-dua dengan prosentase minyak solar $5 \%$, jumlah bakteri sebanyak $1,5 \times 10^{5} \mathrm{CFU} / \mathrm{mL}$ pada hari ke 7 dan $0,5 \times 10^{5} \mathrm{CFU} / \mathrm{mL}$ pada hari ke 14 . Pertumbuhan bakteri juga mengalami penurunan pada prosentase minyak solar $10 \%$ hari ke 14 yang semula berjumlah $6,9 \times 10^{5} \mathrm{CFU} / \mathrm{mL}$ menjadi $0,7 \times 10^{5} \mathrm{CFU} / \mathrm{mL}$ (Tabel 4).

Tabel 4. Pertumbuhan isolat bakteri pada prosentase minyak solar $5 \%$ dan $10 \%$

\begin{tabular}{lccc}
\hline Prosentase solar (\%) & $\begin{array}{c}\text { Kepadatan } \\
\text { hari ke-0 }\end{array}$ & Kepadatan hari ke-7 & Kepadatan hari ke-14 \\
\hline 5 & 54 & 140000 & 110000 \\
5 & 54 & 150000 & 50000 \\
Rerata & & 145000 & 80000 \\
Standar deviasi & & 7071,0678 & 42426,4069 \\
\hline 10 & 54 & 610000 & 50000 \\
10 & 54 & 690000 & 70000 \\
Rerata & & 650000 & 60000 \\
Standar deviasi & & 56568,5425 & 14142,1356 \\
\hline
\end{tabular}

Pertumbuhan bakteri pada kedua prosentase beranekaragam. Jumlah sel bakteri Vibrio alginolyticus mengalami peningkatan seiring bertambahnya prosentase minyak solar. Bakteri Vibrio alginolyticus diketahui dapat mendegradasi minyak pada konsentrasi tertentu. Menurut Nasikhin dan Shovitri (2013), degradasi minyak dapat diduga dengan mengetahui pengurangan atau penambahan jumlah sel mikroba tiap satuan waktu. Pertumbuhan bakteri Vibrio alginolyticus pada ke-dua pengulangan mengalami kenaikan pada hari ke 7 dan penurunan pada hari ke 14 . Berdasarkan fase pertumbuhan, hari ke 7 merupakan fase eksponensial (fase dimana pertumbuhan bakteri sangat tinggi) sedangkan hari ke 14 merupakan fase kematian (fase dimana pertumbuhan bakteri sangat rendah).

Menurut Yetti (2016), bakteri Vibrio merupakan salah satu bakteri sedimen laut yang dapat mendegradasi rantai karbon dari senyawa Polyaromatic Hydrocarbons (PAHs). Hal ini disebabkan karena bakteri dapat memecah rantai karbon dengan bantuan enzim monooksigenase dan enzim dioksigenase untuk menghasilkan nutrisi yang kemudian dimanfaatkan bagi pertumbuhan (Hasyimuddin et al., 2016).

Menurut Umroh (2011), penurunan sel bakteri dapat disebabkan karena berkurangnya kandungan nutrien $\mathrm{N}$ dan $\mathrm{P}$ di dalam sampel, nutrien ini dimanfaatkan bakteri sebagai sumber nutrisi untuk pertumbuhan. Berdasarkan fase pertumbuhan, hari ke 7 merupakan fase eksponensial (fase dimana pertumbuhan bakteri sangat tinggi) sedangkan hari ke 14 merupakan fase kematian (fase dimana pertumbuhan bakteri sangat rendah). Pertumbuhan bakteri pada kedua prosentase beraneka ragam. 
Jumlah sel bakteri mengalami peningkatan seiring bertambahnya prosentase minyak solar. Hal ini disebabkan karena bakteri memanfaatkan unsur karbon yang ada dari minyak solar dan ekstrak yeast. Menurut Nashikin dan Shovitri (2013), karbon merupakan elemen paling dasar untuk seluruh bentuk kehidupan dan karbon dibutuhkan dalam jumlah yang lebih besar dari pada elemenelemen lain.

Histogram degradasi minyak (Gambar 4) dan grafik korelasi waktu pemaparan dan daya degradasi (Gambar 5) diketahui jumlah minyak sisa degradasi menurun berbanding lurus dengan lama periode uji degradasi. Nilai $R$ Square pada histogram degradasi minyak memiliki nilai 0,9549 di prosetase $10 \%$ dan 0,9847 di prosentase $5 \%$. Nilai $R$ Square yang baik yaitu jumlahnya mendekati angka 1 atau dapat dikatakan dapat mewakili $100 \%$ data yang digunakan. Pada nilai $R$ Square degradasi minyak prosentase $10 \%$ dapat mewakili $95,49 \%$ dari data yang digunakan dan pada prosentase $5 \%$ sebesar $98,47 \%$.

Hasil pengamatan dari uji degradasi pada inkubasi selama 7 hari dan 14 hari menunjukan bahwa semua isolat yang diuji mampu mendegradasi minyak solar dengan hasil prosentase yang berbeda. Pada periode 7 hari, bakteri ulangan pertama mampu mendegradasi minyak pada prosentase $5 \%(0,5 \mathrm{~mL})$ sebesar $26,08 \%$, prosentase $10 \%(1 \mathrm{~mL})$ sebesar $28,39 \%$ dari jumlah total minyak. Pada periode 14 hari, bakteri pada ulangan pertama mampu mendegradasi minyak pada prosentase $5 \%(0,5 \mathrm{~mL})$ sebesar $56,88 \%$, prosentase $10 \%(1 \mathrm{~mL})$ sebesar $71,61 \%$ dari jumlah total prosentase minyak awal.

Isolat bakteri Vibrio alginolyticus ulangan ke-dua memiliki perbedaan besaran prosentase minyak yang terdegradasi, pada periode 7 hari prosentase $5 \%(0,5 \mathrm{~mL})$ sebesar $38,4 \%$, prosentase $10 \%$ (1 mL) sebesar 19,15\% dari jumlah total prosentase minyak awal. Pada periode 14 hari bakteri Vibrio alginolyticus ulangan ke-dua mampu mendegradasi minyak pada prosentase $5 \%(0,5 \mathrm{~mL})$ sebesar $49,18 \%$, prosentase $10 \%$ (1 mL) sebesar $80,85 \%$ dari jumlah total prosentase minyak awal.

Uji One-Way ANOVA dilakukan pada pertumbuhan bakteri hasil seleksi prosentase $2 \%$ minyak solar. Pada hasil uji analisa One-Way ANOVA didapatkan nilai Sig. pengulangan pertama yaitu 0,482 dan pada pengulangan ke-dua sebesar 0,816 pada data pertumbuhan prosentase $2 \%$. Pada uji normalitas diketahui kedua ulangan memiliki nilai Sig. >0,05 maka data berdistribusi normal. Menurut Oktaviani et al. (2014), apabila nilai Sig. pada uji normalitas bernilai $>0,05$ maka data berdistribusi normal.

Pada hasil uji homogenitas diperoleh nilai signifikansi (Sig) sebesar 0,173 . Nilai signifikansi (Sig) yang diperoleh 0,173 > 0,05 maka ke-dua data pengulangan bersifat homogen sehingga asumsi homogenitas dalam uji one-way ANOVA tepenuhi. Uji ANOVA dilakukan untuk melihat perbedaan rata-rata pertumbuhan bakteri pada prosentase $2 \%$. Nilai signifikansi (Sig) yang didapat pada ANOVA, yaitu 0,319>0,05 maka pertumbuhan antar ke-dua pengulangan adalah sama atau tidak ada perbedaan. Apabila nilai signifikansi (Sig) yang didapat $<0,05$ maka ada perbedaan ratarata pertumbuhan pada tiap pengulangannya.

Pada uji degradasi minyak solar prosentase $5 \%$ dan $10 \%$, nilai mean/rerata minyak solar sisa degradasi mengalami penurunan kadar minyak seiring dengan berjalannya waktu (periode) isolasi, pernyataan ini juga didukung oleh hasil uji Tukey HSD (Honestly Significant Difference), yaitu nilai signifikansi periode hari ke-0 hingga hari ke-7 sebesar 0,003 $(<0,05)$, hari ke-0 hingga ke-14 sebesar $0,00(<0,05)$ dan hari ke-7 hingga ke-14 sebesar 0,01 $(<0,05)$. Uji Tukey HSD menjelaskan bahwa pada periode hari ke-0 hingga ke-14 memiliki perubahan/pengurangan prosentase yang secara signifikan. Nilai dunnett $t$ yang diperoleh, yaitu pada periode hari ke-0 hingga hari ke-7 sebesar 0,003 $(<0,05)$, pada hari ke-0 hingga ke-14 sebesar $0.00(<0,05)$ dan pada hari ke-7 hingga ke-14 sebesar 0,007 (Tabel 4.12). Pada hasil uji dunnett $t$ menyatakan pengurangan prosentase minyak solar terbesar berada pada periode hari ke-0 hingga ke-14, hal ini dikarenakan bakteri memiliki waktu yang lebih lama untuk melakukan proses degradasi.

Pada hasil uji degradasi minyak solar dilakukan juga dilakukan uji Paired Sample T test. Hasil uji Paired Sample T test kepadatan bakteri hari ke-0 dan hari ke-7 memiliki nilai signifikansi (Sig.) $0,018(<0,05)$, maka terdapat perbedaan jumlah secara signifikan antara kepadatan bakteri hari ke0 dengan hari ke-7. Perbedaan signifikan ini terjadi karena ada lonjakan pertumbuhan kepadatan bakteri pada uji degradasi hari ke-7. Lonjakan pertumbuhan kepadatan bakteri diduga terjadi karena isolat bakteri berada pada tahap eksponensialnya. 


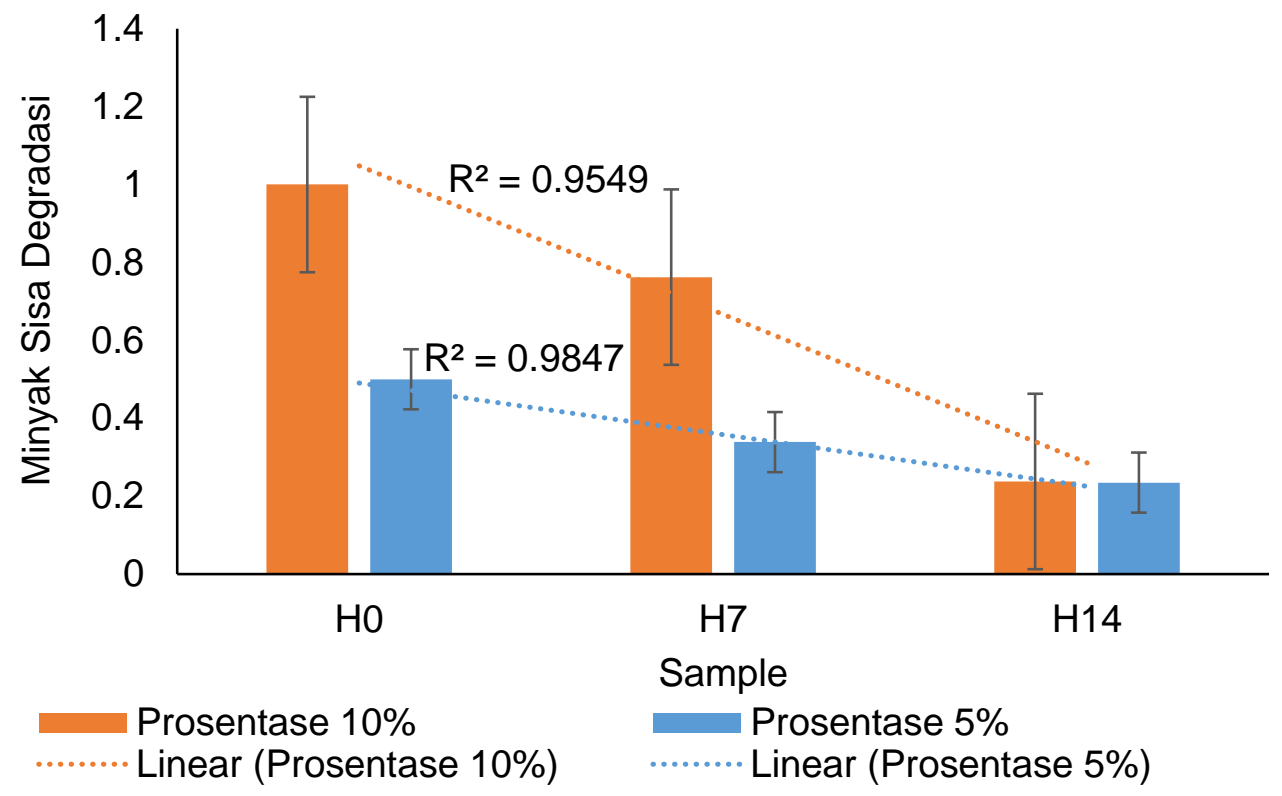

Gambar 4. Histogram Rerata Degradasi Minyak

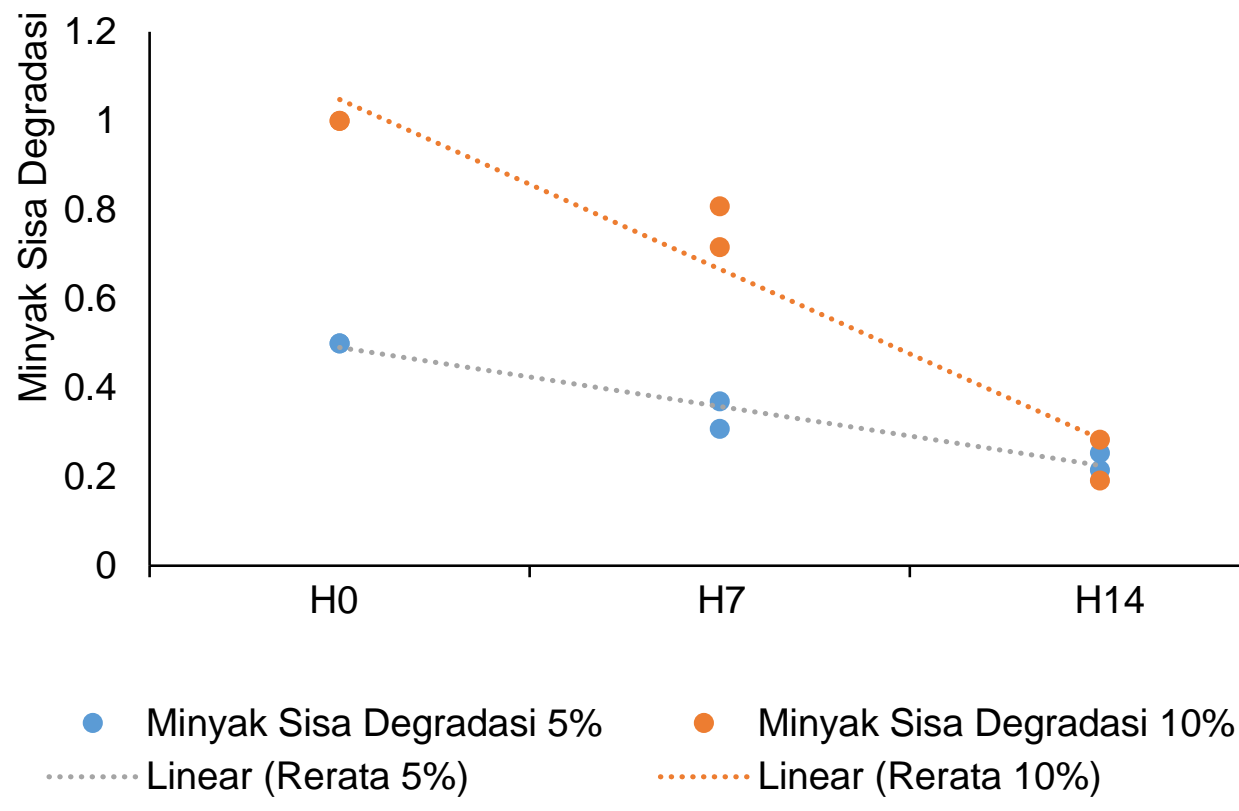

Gambar 5. Grafik Korelasi Waktu Pemaparan Dan Daya Degradasi

Uji Paired Sample T test kepadatan bakteri hari ke-0 dan hari ke-14 memiliki nilai signifikansi Sig. 0,002 $(<0,05)$ maka ada perbedaan kepadatan bakteri Vibrio alginolyticus secara signifikan pada hari ke-0 dan hari ke-14. Hasil uji Paired Sample $T$ test pada kepadatan hari ke-7 dan ke-14 memiliki nilai sig. 0,049 $(<0,05)$, maka terdapat perbedaan secara signifikan pada hari ke-7 dan ke14. Pada hasil uji hari ke-7 dan ke-14 kepadatan bakteri cenderung berkurang, hal ini dikarenakan bakteri telah memasuki fase kematian.

Pada hasil uji Paired $T$ test minyak sisa degradasi hari ke-0 dan ke-7 memiliki nilai signifikan senilai 0,14 (Sig. <0,05), maka terdapat perbedaan signifikan pada jumlah minyak sisa hari ke-0 dan hari ke-14. Pada Paired T test minyak sisa degradasi hari ke-0 dan ke-14 memiliki nilai signifikan 0,012 (Sig. <0,05), maka terdapat pengurangan minyak sisa degradasi secara signifikan pada periode hari ke-7 hingga hari ke-14. Uji Paired $T$ test prosentase minyak sisa degradasi periode 7 hari hingga 14 hari, nilai signifikan 0,034 (Sig. <0,05). Hasil Paired T test hari ke 7 hingga 14 menyatakan bahwa terdapat perbedaan secara signifikan jumlah minyak sisa terdegradasi dari hari ke-7 hingga hari ke-14. Pada uji Test of Between-Subject Effect Nilai signifikansi interaksi 
prosentase awal dan periode sebesar 0,093 (Sig. >0,05), maka prosentase awal dan periode tidak memiliki interaksi.

Hasil dari uji degradasi yang telah dilakukan menyatakan bahwa isolat bakteri Vibrio alginolyticus miliki kemampuan untuk mendegradasi minyak solar pada prosentase tertentu, hal ini juga diperkuat oleh pernyataan dari Imron dan Titah (2018), yang menyatakan bahwa Vibrio alginolyticus merupakan salah satu bakteri yang mampu mendegradasi minyak solar. Variasi dari jumlah besaran minyak solar yang terdegradasi diduga akibat rendahnya jumlah volume minyak solar yang digunakan dan letak atau posisi tabung reaksi pada alat shaker.

Bakteri yang mampu mendegradasi senyawa hidrokarbon dapat disebut sebagai bakteri hidrokarbonoklastik. Vibrio alginolyticus dapat memanfaatkan minyak solar sebagai sumber karbon untuk pertumbuhan dan reproduksi. Sumber karbon pada minyak solar dapat digunakan untuk metabolisme bakteri, tetapi minyak solar juga dapat menjadi racun bagi mikroorganisme karena pada prosentase tertentu efeknya yang menghacurkan membran sel. Proses degradasi minyak solar oleh bakteri hidrokarbonoklastik dapat terjadi karena bakteri memiliki enzim yang mampu memecah rantai karbon. Bakteri hidrokarbonoklastik dapat mengoksidasi senyawa hidrokarbon afiatik dan aromatik dengan menggunakan beberapa jenis enzim untuk memecah rantai karbon, yaitu enzim monooksigenase dan dioksigenase (Hasyimuddin et al., 2016).

Enzim monooksigenase memiliki peranan untuk mengoksidasi senyawa hidrokarbon alifatik menjadi asetil Ko-A yang kemudian dapat dimanfaatkan pada proses katabolisasi siklus asam nitrat, sedangkan enzim dioksigenase memiliki peran untuk membentuk senyawa catechol atau cis-cis muconate dan mendegradasinya menjadi suksinat, piruvat atau asetil Ko-A yang kemudian dimanfaatkan pada proses katabolisasi siklus asam nitrat (Nasikhin dan Shovitri, 2013).

\section{KESIMPULAN}

Setelah melakukan isolasi, didapat 2 isolat bakteri dengan kode isolat ISL 2 dan ISL 3. Kedua isolat bakteri berhasil diidentifikasi sebagai bakteri Vibrio alginolyticus. Bakteri Vibrio alginolyticus memiliki kemampuan untuk mendegradasi minyak solar pada prosentase $5 \%$ dan $10 \%$ dengan periode inkubasi 7 hari dan 14 hari. Bakteri Vibrio alginolyticus hasil isolasi mampu mendegradasi $19,15 \%$ hingga $80,85 \%$ minyak solar. Keberadaan bakteri Vibrio alginolyticus pada sedimen di perairan Pelabuhan Tanjung Mas mampu membantu proses degradasi minyak solar dari aktivitas pelabuhan.

\section{DAFTAR PUSTAKA}

Dharmayanti, I.N.L.P. 2011. Filogenetika Molekuler: Metode Taksonomi Organisme Berdasarkan Sejarah Evolusi. Wartazoa 1(21): 1-10.

Firdaus, S.R., Saputro, S. \& Satriadi, A. 2013. Studi Pengerukan Alur Pelayaran Pelabuhan Tanjung Mas, Semarang. Jurnal Oseanografi, 2(3):274-279.

Fredriksson, N.J., Hermansson, M. \& Willen, B.M. 2013. The Choice Of PCR Primers Has Great Impact On Assessments Of Bacterial Community Diversity And Dynamics In A Wastewater Treatment Plant. University of Gothenburg, Gothenburg, Sweden. PLOS ONE. DOI: 10.1371/journal.pone.0076431.

Handoyo, D. \& Rudiretna, A. 2000. Prinsip Umum Dan Pelaksanaan Polymerase Chain Reaction (Pcr). Pusat Studi Bioteknologi, Universitas Surabaya.sss

Imron, M.F \& Titah, H.S. 2018. Optimization of Diesel Biodegradation by Vibrio Alginolyticus Using Box-Behnken Design. Environmental Engineering Research, 23(4):374-382. DOI : 10.4491/eer.2018.015..

Mijaya, M.R.S., Yanti, N.A., Ardiansyah \& Muhiddin, N.H. 2019. Isolasi dan Seleksi Bakteri Pendegradasi Solar Dari Pelabuhan Penyeberangan Kendari - Wawonii, Sulawesi Tenggara. BioWallacea: Journal of Biological Research, Vol. 6 (2):995-1006 DOI: 10.33772/BioWallacea. v6i2.8825.

Nasikhin, R. \& Shovitri, M. 2013. Isolasi dan Karakterisasi Bakteri Pendegradasi Solar dan Bensin dari Perairan Pelabuhan Gresik. Jurnal Sains dan Seni ITS, 2(2):E84-E88. DOI: 10.12962/j23373520.v2i2.3626 
Nurjanah, I. 2018. Uji Potensi Bakteri Pendegradasi Minyak Solar Di Perairan Pelabuhan Tanjung Perak Surabaya. Fakultas Sains Dan Teknologi Universitas Islam Negeri Sunan Ampel Surabaya.

Oktaviani, M.A. \& Notobroto, H.B., 2014. Perbandingan tingkat konsistensi normalitas distribusi metode kolmogorov-smirnov, lilliefors, shapiro-wilk, dan skewness-kurtosis. Jurnal Biometrika dan Kependudukan, 3(2):127-135.

Pratama, M.P. 2018. Analisis Hubungan Kandungan Minyak Pada Sedimen Dan Kelimpahan Makrozoobenthos Di Perairan Selat Baru Kabupaten Bengkalis Provinsi Riau. Universitas Riau, Pekanbaru.

Ubaidillah, R. \& Sutrisno, H. 2009. Pengantar Biosistemik: Teori dan Praktikum. LIPI Press, Jakarta.

Umroh. 2011. Bioremidiasi Pencemaran Minyak Di Sedimen Pantai Balongan, Indramayu Dengan Menggunakan Bakteri Alcanivorax Sp. TE-9 Skala Laboratorium. Akuatik. 5(2):23-31

Wulandari, S.Y., Yusuf, M. \& Muslim. 2014. Kajian Konsentrasi Dan Sebaran Parameter Kualitas Air Di Perairan Pantai Genuk, Semarang. Buletin Oseanografi Marina. 3(1):9-19. DOI: 10.14710/buloma.v3i1.11213. 